\title{
Beberapa Permasalahan dan Tantangan dalam Industrialisasi di Indonesia
}

\author{
Oleh : Edy Suandi Hamid
}

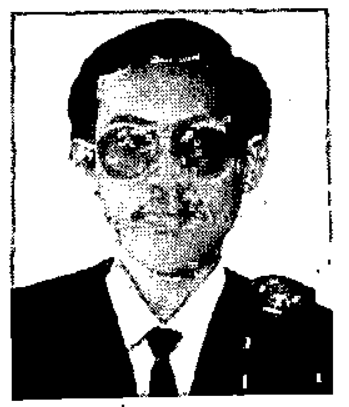

Edy Suandi Hamid, adalah dosen negeri yang dipekerjakan pada Fakultas Ekonomi Universitas Islam Indonesia, disamping juga sebagaistaf penelitl pada Pusat Penellian Pembangunan Pedesaan dan Kawasan (P3PK) UGM dan Sekretaris Ikatan Sarjana Ekonomilndonesia DIY. Lahir dl Tanjung Enim 11 Desember 1957, dan menyelesaikan studl dari FE UGM jurusan IImu ekonomi dan studi pembangunan (Umum), april 1983 S1 serta S2 darl Faculty of Economic Thammasat University, Bangkok 1990.

Pernah menjadi wartawan dan redaksl ekonomi harian Kedaulatan Rakyat, serta PImpinan Redaksi Majalah Equilibrium (FE UGM). KInI aktlf dalam keglatan penelitian yang menyangkut masalah pedesaan. Menulis bukuPengantar TeoriPerilaku Konsumen (bersama Drs. Effendy Arl, 1985), menyunting buku Kredit Pedesaan di Indonesia (bersama Prof. Mubyarto, 1986) dan Meningkatkan EfisiensI Nasional (bersama Prof. Mubyarto, 1987).

..... Dalam hubungan ini saya ingin menekankan bahwa sebagai negara yang sedang membangun adalah wajar bagi kita untuk melindungi industri-industri dalam negeri yang baru mulai berkembang. Sebab industri-industri inilah yang akan menjadi tulang punggung ekonomi kita di masa datang. Tetapi kita perlu pula menyadari bahwa perlindungan tidak dapat diberikan untuk selama-lamanya. Sebab hal itu justru akan mematikan dorongan bekerja keras untuk meningkatkan efisiensi. Perlindungan yang terus menerus juga membebani masyarakat. Sebabnya adalah karena masyarakat luas harus membayar keperluannya dengan harga yang lebih tinggi ...... Dalam kurun waktu yang sesingkat-singkatnya industri yang dilindungi harus menjadi dewasa dan mampu untuk berdiri di atas kakinya sendiri (Pidato Kenegaraan Presiden RI, 15 Agustus 1992)

Pendahuluan

Berbicara mengenai industrialisasi, maka perhatian kita secara umum akan tercurah pada sektor industri pengolahan (manufacturing sector). Industrialisasi terutama mengandung makna untuk meningkatkan peran sektor ini dalam perekonomian, yang dalam indikator ekonomi makro dapat dilihat dari kontribusinya atas Produk Domestik Bruto (PDB). Untuk meningkatkan peran ini, berarti menuntut tersedianya sumber daya yang cukup, apakah itu modal, teknologi maupun tenaga kerjanya, terutama yang mempunyai keahlian (skills) tertentu. Tetapi orang atau pelaku bisnis akan mau melakukannya, kalau produk yang dihasilkan itu ada yang meminta atau 
membelinya. Berarti terkait pula disini unsur demand-nya, unsur pemasarannya. Tak ada yang mau meningkatkan produksi kalau hasilnya tak terjual. Pasar ini mungkin menjadi kurang ekonomis kalau cakupannya terbatas.

Tuntutan economies of scale inilah yang menantang pelaku bisnis dan pemerintah untuk dapat menciptakan pasar yang luas, yakni bisa mengisi pasar domestik dan dapat pula menembus pasaran internasional. Karena itu cukup memadai kalau Boediono (1987) mengartikan industrialisasi sebagai "proses percepatan pertumbuhan produksi barang industri yang dilaksanakan dalam negeri, yang diimbangi dengan pertumbuhan yang serupa di bidang permintaannya, baik yang berasal dari dalam maupun luar negeri".

Untuk mendorong dan mengembangkan industri ini agar memiliki daya saing di pasaran (domestik maupun dunia), suatu pemerintah umumnya memberikan proteksi pada tahap awal perkembangannya. Tetapi proteksi ternyata sering menimbulkan masalah yang berkepanjangan. Sekali proteksi diberikan, biasanya menjadi sukar ditarik kembali. Akibatnya, industri menjadi tidak efisien, konsumen harus membayar lebih mahal, dan akhirnya sukar bersaing di pasar internasional jika tanpa diberikan insentif tertentu.

Jadi industrialisasi bukanlah sesuatu yang sederhana. Ia mengáit berbagai aspek, ekonomi, teknologi, kebijaksanaan pemerintah, sosial dan sebagainya. Akan tetapi, bagaimanapun peliknya proses industrialisasi ini, ia sudah merupakan sesuatu yang tampaknya disepakati sebagai suatu "alat" untuk meningkatkan tarap hidup masyarakatnya. Kemajuan sektor industri dianggap sebagai tolok ukur ini tampaknya dapat dipahami mengingat dari negara-negara yang tergolong kaya saat ini, sektor industrinya mempunyai peran utama dalam perekonomiannya. Sehingga para ahli ekonomi pembangunan banyak yang mengukur keberhasilan pembangunan suatu bangsa dengan melihat antara "lain perkembangan sektor industri manufaktur dalam struktur próduksi atau dalam komposisi PDB maupun dalam struktur ekspornya (Chenery, 1979; Anwar, 1987). Oleh karena itu, tidak mengherankan pula jika dalam mengatasi problema pembangunan ekonomi di negara-negara berkembang, jalan keluar melalui industrialisasi hampir selalu menjadi rekomendasi pembangunan yang utama. Industrialisasi dianggap sebagai "resep mujarab" untuk mengejar ketertinggalan dari pembangunan yang ada di negara-negara berkembang. Apa yang terlihat di negaranegara yang tergolong maju sant ini, ataupun negara-negara yang dianggap sudah berhasil melepaskan diri dari predikat negara sedang berkembang, seperti "empat naga Asia" : Korea selatan, Singapura, Hongkong dan Taiwan dianggap sebagai kisah sukses dari industrialisasi. Dengan demikian tidak aneh jika negara-negara sedang berkembang menganggap bahwa industrialisasi ini merupakan "kunci" dari pembangunan (Hamid, Edy Suandi dan Hudiyanto, 1990).

\section{Industrialisasi di Indonesia}

Dalam mengukur derajad industrialisasi suatu negara, UNIDO (United Nations Industrial Development Organisation, 1974) memilah negara-negara berdasarkan sumbangan sektor industrinya atas P.DB menjadi 4 kelompok, yaitu, (a) negara "non industri" (non industrial country), jika sumbangan industri (manufaktur) terhadap PDB kurang dari 10\%; (2) negara yang "industrinya sedang tumbuh" atau dalam proses industrialisasi (industrializing country) bila perannya antara 10 hingga 20 persen; (3) negara "semi industri" (semi industrialized country) jika sumbangan antara 20 hingga 30 
persen; dan (4) "negara industri" (industialized country) apabila kontribusi sektor industri ini melebihi 30\% dari PDB.

Dengan menggunakan klasifikasi dari UNIDO ini, maka dapat diketahui bahwa Indonesia -- tanpa memasukkan industri minyak dan gas -- masih berada dalam kelompok negara yang industrinya sedang tumbuh (industrializing country). Data Bank Dunia (IBRD; 1989) menunjukkan bahwa sumbangan sektor industri manufaktur atas PDB Indonesia tahun 1987 hanya 14 persen. Status inipun (jika menggunakan data atas dasar harga konstan 1983) baru di capai Indoensia tahun 1980. Artinya, sebelum tahun itu Indonesia masih tergolong negara non industri. Posisi kita sekarang, yang masuk dalam jajaran negara dalam proses industrialisasi ini, menempatkan Indonesia sebagai satu-satunya dari negara ASEAN (di luar Brunai) yang masih dalam klasifikasi tersebut. Empat negara ASEAN lainnya, yakni Singapura (29 persen), Thailand (24 persen), Malaysia (22 persen), dan Filipina (25 persen), sudah diklasifikasikan sebagai "negara semi industri" (Worl Bank / IBRD, 1989 dan EIU, 1989). Dengan perkembangan yang pesat dan terus menerus dari sektor industrinya, dapat diperkirakan bahwa sumbangan sektor industri atas PDB Singapura saat ini sudah melampaui 30 persen, dan menempatkannya sebagai satusatunya negara ASEAN yang berpredikat sebagai negara industri (baru).

Pada saat perkembangan laju pertumbuhan industri yang pesat di tahun 1980-an, timbul optimisme bahwa Indonesia akan dapat mensejajarkan diri dengan negara ASEAN lainnya, yakni masuk dalam kelompok negara "semi industri". Target ini dapat diharapkan bisa dicapai akhir pelita IV atau di akhir tahun 1980-an yang lalu. Namun baru saja harapan tersebut muncul, keadaan sektor industri (dan perekonomian secara keseluruhan) sudah berbalik mengalami pertumbuhan yang menurun. Pertumbuhan dua digit yang terjadi sebelumnya, tidak terulang lagi. Tahun 1982, sektor industri hanya tumbuh $1,2 \%$, dan untuk tahun 1983 , 1984 dan 1985 masing-masing hanya 2,2\%, $6,1 \%$ dan $6,2 \%$. Di pertengahan dasawarsa 1980 -an pun berbagai pendapat sudah "memastikan" bahwa sasaran tersebut tidak akan tercapai (Hamid, Edy Suandi, 1987). Kenyataan hal ini memang tidak mewujud. Pada akhir pelita IV sumbangan sektor industri atas PDB diperkirakan baru mencapai 16,6\% (Djojohadikusumo, 1989). Apakah posisi yang diinginkan tersebut bisa dicapai dalam waktu dekat di dasawarsa 1990-an ini, akan sangat tergantung dari pertumbuhan industri itu sendiri, yang paling tidak harus tumbuh dua kali lipat dibanding pertumbuhan ekonomi selama lima-enam tahun mendatang. Dan ini jelas bukanlah sesuatu yang mudah mengingat sekarang ini pasar domestik kian sempit,'dan pasar ekspor juga menghadapi persaingan yang ketat disamping adanya proteksi yang meningkat di dunia.

Namun demikian, jika dalam penghitungan kontribusi sektor industri terhadap PDB itu dimasukkan pula unsur industri pengolahan dari minyak dan gas, maka saat ini Indonesia sudah tergolong sebagai negara semi industri. Sekarang ini sumbangan sektor industri dalam produksi nasional sudah mencapai 21 persen (Pidato Kenegaraan Presiden RI, 15/8/1992). Persoalannya adalah sumbangan dari sektor migas ini sangat fluktuatif, dan dalam jangka panjang diperkirakan juga akan menurun perannya dalam ekonomi Indonesia.

Ketertinggalan sektor industri Indoensia dibandingkan dengan negara ASEAN lainnya saat ini, tidak bisa dilepaskan dari terlambatnya negara kita memulai proses industrialisasi ini. Proses industrialisasi di Indonesia baru di mulai secara serius pada dasawarsa 1970-an, yang memulai dengan upaya mengolah hasil pertanian dan menekankan pada industri substitutsi impor (ISI). kenyataan ini membuat kita "segan" 
untuk bersaing atau membuka pasar kita atas produk industri sejenis dari negara lain, termasuk dari sesama negara ASEAN sekalipun. "Ke-belumsiapan" kita untuk bersaing dengan mitra di ASEAN ini secara jelas dikemukakan Prof. Ali Wardhana (kala itu menjadi Menko Ekuin) Kepada Asia Week (May, 1986, lihat pula Hamid, Edy Suandi 1990) dengan mengatakan :

"........ you have to understand that the other members had a 20 to 30 year headstart on Indonesia. We really only began industrialization (about 1975); so after ten years, can we compete with Singapore with its higher technology? We agree to preferential trade, but gradually, in industries that we are strong. We are not at the level of Thailand where non-oil exports are very competitive, very efficient..........."

Pernyataan diatas menyuratkan bukan saja "kebelumsiapan" kita untuk berkompetisi dengan produk industri dari sesama ASEAN, tetapi lebih dari itu menyiratkan pengakuan ketidakefisienan sektor tersebut, sehingga perlu diberikan proteksi. Perbedaan dalam tahap industrialisasi dan kita merasa paling tertinggal -- ini pula yang menyebabkan gagasan pembentukan perdagangan bebas ASEAN (ASEAN Free Trade Area) yang dilontarkan Singapura dan didukung negara ASEAN lainnya, pada masa lalu selalu ditolak Indonesia. Karena, tanpa kesiapan industri dalam negeri untuk berkompetisi secara bebas dengan sesama ASEAN, maka pelaksanaan gagasan tersebut akan menempatkan kita pada posisi yang tidak diuntungkan, terutama dalam jangka pendek (Hamid, Edy Suandi, 1990).

Namun demikian berkembangnya "mode" membèntuk blok-blok ekonomi, terutama di kalangan negara maju, telah memaksa Indonesia mengkaji ulang pemikirannya dalam hal integrasi ekonomi regional ini, khususnya di kalangan anggota ASEAN. Dalam KTT ASEAN ke-4 yang diadakan di Singapura awal tahun ini, Indonesia mensepakati terbentuknya AFTA (ASEAN Free Trade Area), yang mulai diberlakukan secara bertahap mulai 1 Januari 1993, dan diperkirakan bisa tuntas pelaksanaannya selama 15 tahun. Dengan kesepakatan ini mau tak mau sektor industri Indonesia harus siap bersaing secara bebas dengan industri sejenis dari sesama anggota ASEAN. Jika industri kita tetap tidak efisien, maka akibatnya jelas sangat merugikan, karena akan kalah bersaing dan pasamya akan direbut oleh produsen dari negara ASEAN lainnya.

\section{Industrialisasi, Proteksi dan Efisiensi}

Di kalangan negara ASEAN, Filipina sudah memiliki sejarah industrialisasi yang paling panjang, yang memulainya sejak awal 1950-an. Sementara Malaysia, Singapura dan Thailand baru mulai satu dekade setelah Filipina, dan Indonesia menyusul lebihdua dekade setelah Filipina tersebut (Ariff dan Hoe, 1988). Akan tetapi lambannya perkembangan industrialisasi di Indoensia ini tidak pula bisa dilepaskan dari perlindungan yang berlebihan yang diberikan kepada sektor industri dalam negeri itu sendiri. Selama lebih dari satu dekade proses industrialisasi yang terkonsentrasi pada strategi "melihat ke dalam" atau inward looking policy, yang dimaksudkan untuk menggantikan barangbarang impor, telah menimbulakan kemanjaan industri dalam negeri. Bank Dunia (1987) memasukkan Indonesia dalam negara yang berorientasi ke dalam secara moderat (moderately inward oriented), yang dilihat dari aspek struktur insentif, proteksi efektif dan perlindungan nontariffnya.

Ada berbagai instrumen yang digunakan dalamupaya melindungi industri dalam negeri. Di samping. lewat pengenaan tarif biaya masuk yang tinggi (custom duties), juga melalui hambatan-hambatan bukan tarif (nontariff barriers). Hambatan nontariff yang digunakan antara lain pembatasan impor (import quotas), subsidi untuk produsen domestik, keharusan memiliki lisensi impor, 
larangan impor sampai adanya tambahan prosedural administratif yang lebih panjang untuk komoditi yang hendak dilindungi. Suatu penelitian yang dilakukan peneliti Malaysia dan Singapura telah menempatkan Indonesia sebagai negara yang paling banyak memasang hambatan non-tariff di ASEAN (Haroon dan Mansoor Md.Isa, 1987; Tin, 1987, atau Hamid, 1990). Terlalu banyak hambatan non-tariff dalam sektor industri kita ini juga didukung oleh penelitian dari LPEM UI (1986), yang menegaskan tentang meluasnya hambatan non-tariff untuk menggantikan hambatan.lewat tarif, sehingga menimbulkan berbagai akibat yang tidak mengutungkan.

Kurangnyä iklim persaingan bagi sektor industri, terutama industri besar dan sedang, telah membuat banyak industri kita "dituduh" kurang efisien dan berkembang dalam kondisi ekonomi biaya tinggi (high cost economy). Perhitungan yang ada memperkuat pula "tuduhan" tersebut. Humaidi dan Hasibuan (1988) menunjukkan perhitungan yang menggambarkan telah terjadinya penurunan tingkat efisiensi industri besar dan sedang selama kurun waktu 1974-1975. Dengan menggunakan ukuran rasio antara nilai tambah dengan biaya madya menurun dari $57,6 \%$ (1974) menjadi 53,9\% (1985). Beberapa industri yang mengalami penurunan tingkat efisiensinya dalam kurun waktu tersebut antara lain ISIC 31 (makanan, minuman dan tembakau) yang menurun dari 71,5 menjadi 51,1 dan ISIC 36 (barang galian bukan. logam, kecuali minyak dan batubara, dari 61,6 ke 54,8) serta ISIC 39 (industri pengolahan lainnya, dari 119,9 menjadi 53,8). Angka-angka ini mencerminkan menurunnya penciptaan nilai tambah (value added) sebagai akibat meningkatnya pengeluaran-pengeluaran untuk pembèlian bahan baku, bahan penolong, jasa-jasa industri lainnya, dan sebagainya.

Selama pasar dalam negeri dilindungi, dan devisa dari sektor lain masih lancar mengalir untuk membiayai impor-impor Indonesia, ketidakefisienan serta strategi industrialisasi yang berorientasi pada ISI ini tidaklah banýak menimbulkan masalah. Namun kenyataan yang terjadi pada awal 1980-an adalah kondisi sebaliknya. Resesi ekonomi dunia, kejenuhan pasar domestik serta penurunan drastis harga minyak di pasar dunia -- yang berarti menurunnya secara drastis penerimaan devisa negara dari ekspor -- telah mengingatkan akan kerapuhan sektor industri ini, dan memaksa pula untuk lebih "melihat keluar" (outward looking) dalam pengembangan dalam negeri. Pergeseran kearah orientasi ekspor (export oriented industry) tersebut semakin ditekankan sejak beberapa tahun terakhir ini.

Tahun 1982 telah ditandai dengan hal yang dramatis dari perkembangan industri nasional. Kalau sebelumnya pertumbuhan industri manufaktur selalu di atas rata-rata pertumbuhan ekonomi nasional, dan selalu dengan bilangan dua digit, maka tahun 1982 pertumbuhan sektor industri manufaktur hanya $1,2 \%$. Hal ini terjadi karena melemahnya permintaan dan adanya kebijaksanaan konstraksi dari pemerintah sebagai akibat turunnya harga dan permintaan minyak di pasaran dunia. Penerimaan devisa dari expor migas yang tahun 1981 mencapai puncaknya dan US\$ 20663,2 juta menjadi US\$ 18399,1 juta pada tahun 1981, dan ini terus menurun yang pada tahun 1988 tinggal US\$20663,3 juta. Pada awal anjloknya harga minyak ini pemerintah telah melakukan kebijaksanaan penjadwalan berbagai proyek industri, penurunan pengeluaran pembangunan serta menerapkan kebijaksanaan uang ketat (tight monetary policy). Kebijaksanaan-kebijaksanaan ini jelas sangat mempengaruhi sektor industri, seperti tercermin dari "terhempasnya" laju industri tahun-tahun tersebut. Sektor industri baru bangkit lagi dalam tiga tahun terakhir ini, dengan tingkat pertumbuhan rata-rata di atas 10 persen per tahun (Tempo, 22/8/1992).

Proses mengawali industrialisasi dengan 
ISI merupakan suatu hal yang umum dilakukan oleh negara-negara berkembang, termasuk oleh negara yang kini masuk jajaran NICs, seperti Korea dan Taiwan (Poot, 1990). Besarnya peluang pasar di dalam negeri, dan perlindungan serta dorongan yang diberikan pemerintah, telah memberikan hasil yang baik bagi perkembangan sektor industri ini. Berbagai barang yang tadinya diimpor, terutama bahan sandang (ISIC 32) dan pangan olahan (ISIC 31), telah bisa dipenuhi sendiri. Selama periode' $1966-1983$ pertumbuhan sektor industri (atas harga konstan 1973) diperkirakan rata-rata $11,4 \%$ per tahun, jauh di atas laju pertumbuhan PDB yang $7 \%$. Sedang untuk periode 1978-1985 (atas dasar harga konstan 1983), pertumbuhan sektor industri ini rata-rata $10,2 \%$ per tahun, atau Iebih dua kali lipat dari pertumbuhan PDB yang hanya $1,6 \%$ per tahun. Karena itu dapat dikatakan dari segi perkembangan outputnya, strategi ini sudah menunjukkan hasil yang" baik.

Akan tetapi, sekali lagi patut dicatat, bahwa rangsangan investasi -- yang telah menyebabkan berkembangnya output industri ini -- karena adanya proteksi yang luas dari pemerintah. Hal ini telah merangsang investor lokal maupun asing untuk terjun di bisnis manufaktur ini. Sebagai konsekuensinya :

"........ Indonesian manufactures are priced higher at the domestic market than they would be, if imported directly form abroad. Many of these sectors are not really the kind of the country which has a comparative advantage........." (LPEM-UI, 1986).
Semakin ketatnya persaingan di pasar dunia, dan juga kian diharapkannya peran sektor industri dalam mendukung perekonomian secara keseluruhan, agaknya telah membuat pemerintah secara bertahap mengurangi proteksi ini. Pidato Presiden yang dikutip pada awal tulisan ini, mencerminkan adanya keinginan kuat untuk mengurangi proteksi itu. Namun demikian, kenyataan yang ada menunjukkan bahwa proteksi itu masih dinikmati oleh sementara kalangan yang mempunyai lobby kuat dengan para penyusun kebijaksanaan.

\section{Kandungan Impor.}

Untuk menganalisis perkembangan industri ini, maka perlu kiranya kita lihat sejauh mana peran atau kandungan impor (import contents) dalam produksi yang dihasilkan. Kandungan impor ini tidak saja menyangkut bahan baku ataupun bahan penolongnya, tetapi juga menyangkut barangbarang mesin, teknologi maupun tenaga ahlinya. Dapat diketahui sampai saat ini kandungan impor ini masih cukup tinggi. Bahkan untuk produk-produk tertentu bisa mencapai $95 \%$, seperti yang terjadi pada industri tenun. Demikian pula untuk industri bir, kendaraan bermotor, perkapalan, dan sebagainya, masih tinggi ketergantungan pada bahan impor (Humaidi dan Hasibuan, 1988). Namun demikian dapat dicatat, secara umum porsi kandungan impor ini semakin menurun. Data perkembangan terakhir dari industri besar dan sedang menunjukkan bahwa bahan baku lokal semakin meningkat, seperti ditunjukkan dalam tabel berikut ini. 
Tabel 1 : Komposisi Penggunaan Bahan Baku Industri Besar / Sedang Menurut Kelompok Besar Industri dan Asal Bahan Baku ( dalam \% )

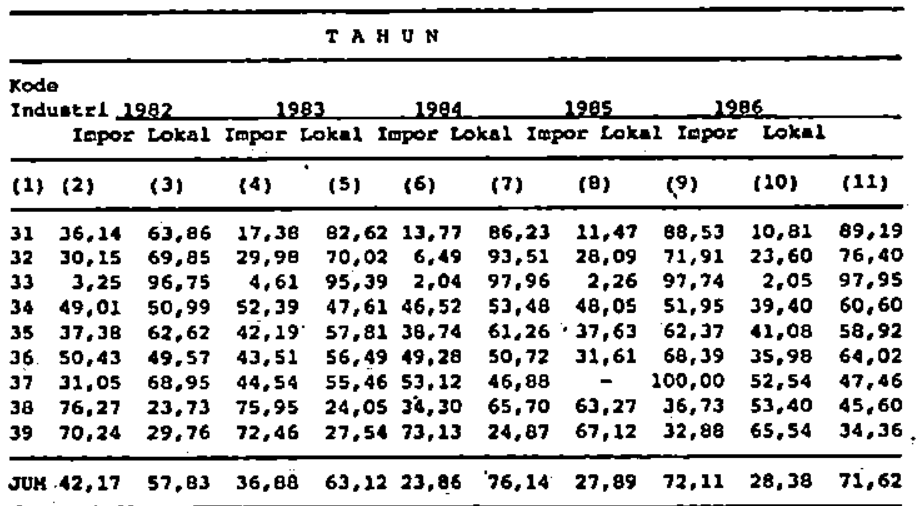

Sumber $\quad \vdots \quad$ Biro Pusat Statistik (1988), Indikator Industri 1983.

Keterangan : ISIC 31 industri makanan, minum dan tembakau; $32=$ tekstil, pakaian jadi dan kulit; $33=$ industri kayu dan barang dari kayu; 43 = industri kertas dan barang dari kertas, percetakan dan penerbitan; 35 = industri kimia dan barang darikimia, minyak bumi, batubara, karet dan barang dari plastik; 36 = industri barang galian bukan logam, kecuali minyak bumi dan batu bara; 37 = industrilogam dasar, 38 = industribarang dari logam, mesin dan perlengkapannya; 39 = industri pengolahan lainnya.

Dari data ini tampak bahwa tidak semua industri mengalami penurunan kandungan impormya. Pada industri yang masuk dalam kelompok ISIC 35 (industri kimia dan barang-barang kimia, minyak bumi, karet dan sebagainya) dan ISIC 37 (industri logam dasar) kandungan impornya justru meningkat dari masing-masing $37,38 \%$ dan $31,05 \%$ pada tahun 1982 , menjadi $41,08 \%$ dan $52,54 \%$ tahun 1986. Peningkatan impor ini dapat terjadi antara lain karena berkembangnya jenis industri itu sendiri, sehingga meningkatkan impor teknologi ataupun peralatan modern untuk menunjang perkembangan tersebut.

Jika kecenderungan semakin menurunnya kandungan impor atas barang industri ini terus'berlanjut, dan ini lebih banyak terjadi karena kekuatan pasar, maka hal ini akan memperkuat 'struktur industri kita di masa yang akan datang. Karena industri yang berkembang ini adalah industri yang efisien dan didasarkan atas keunggulan komparatif yang kita miliki. Tentu saja pernyataan ini benar jika industri tersebut memperoleh pasarnya bukan karena proteksi dan subsidi oleh negara. Kebijaksanaan yang bersifat proteksionis pada akhirnya justru akan menimbulkan berbagai distorsi-distorsi baru dalam perekonomian secara keseluruhan.

Berbagai pernyataan diatas tidaklah bermaksud menilai bahwa semua proteksi ini tidak perlu diberikan untuk pengembangan sektor industri. Proteksi sejak dulu sudah ada, dan hingga sekarang, pada masa atau era globalisasi (?) ini, masih terus bermunculan, termasuk di negara maju yang sering menyerukan perdagangan bebas ! Namun proteksi industri ini tidak pantas kalau terusmenerus diberikan, dengan alasan untuk melindungi "infant industry" (industri bayi). Perlindungan kepada infant industry memang bisa dan tampaknya disepakati secara internasional. Masalahnya, sampai beberapa lama suatu industri masih bisa diklasifikasikan sebagai "industri bayi" sehingga harus diproteksi' ?? Perlindungan 
yang meluas tanpa melihat potensi pengembangan industri itu sendiri, akan berakibat justru merugikan, yang biasanya menimbulkan ketergantungan berkepanjangan akan proteksi, serta distorsi dalam perekonomian. Keberhasilan industrialisasi yang kokoh mensyaratkan adanya selektivitas dalam memilih industri yang. ingin dikembangkan, dan mungkin perlu dilindungi dalam tahap awalnya. Dengan kata lain industri yang mempunyai kemungkinan ditingkatkan efisiensi dan daya saingnya-lah yang ditumbuhkan. Karena industri seperti ini tak memerlukan perlindungan terus-menerus, atau diproduski dengan biaya tinggi dan membebani konsumen dengan harga produk yang mahal.

\section{Ekspor Hasil Industri}

Sebagaimana disinggung di muka, perhatian yang lebih luas untuk pasar ekspor hasil industri baru digarap serius menjelang pertengahan 1980-an. Untuk mendorong ekspor ini, berbagai insentif diberikan kepada eksporter, baik berupa kredit ekspor yang murah, dana kompensasi ekspor ( lewat sertifikat ekspor), dan pembebasan bea masuk untuk bahan baku untuk produk ekspor. Berbagai kebijaksanaan untuk mendorong ekspor produk industri dan produk lainnya, yang diambil setelah 1985 antara lain penyederhanaan perosedur dan pengawasan ekspor; penurunan pajak ekspor untuk beberapa komoditi antara lain minyak sawit; penghapusan beberapa lisensi ekspor; perluasan kridit murah tidak hanya untuk eksporter, tetapi juga untuk produsennya, dan sebagainya (Bank Indonesia, berbagai tahun). Ekspor hasil industri memang diharapkan dapat mengkompensasi penurunan penerimaan devisa sebagai akibat merosotnya penerimaan devisa minyak kita, yang sudah menjadi tulang punggung ekonomi sejak 1970-an.

Berbagai kebijaksanaan dan dorongan pemerintah untuk menggalakkan industri berorientasi ekspor ini telah merangsang para investor untuk melaksanakan investasi dengan mengharap pasar internasional sebagai sasaran pemasarannya. Data terakhir menunjukkan investor, baik PMDN maupun PMA, yang mengarahkan industrinya untuk ekspor semakin meningkat. Tahun 1986 proyek PMDN yang berorientasi ekspor baru $50 \%$, dan ini meningkat menjadi $90 \%$ pada tahun 1989,. Sedangkan untuk proyek PMA pada kurun waktu yang sama meningkat dari $21 \%$ menjadi 82\% (Pangestudan Habir, 1989; Sandli dan Thee Kian Wie, 1990). Apakah upaya ini akan berhasil dalam waktu singkat, akan sangat tergantung pada kemampuan produsen kita ini dalam bersaing di pasaran dunia dan menjawab tantangan yang dikemukakan di bawah ini.

Upaya untuk mengembangkan ekspor hasil industri dewasa ini jelas merupakan pekerjaan dan tantangan yang sulit bagi Indonesia. Pertama, struktur produksi industri dalam negeri yang sudah terlanjur banyak yang dihinggapi "high cost economy" harus dibenahi untuk meningkatkan daya saingnya dipasaran dunia. Tanpa adanya kemampuan untuk bersaing di pasar internasional, maka dapat dipastikan industrialisasi yang berorientasi ekspor ińi akan mengalami kegagalan. Tantangan yang kedua adalah menyangkut kondisi perdagangan internasional sendiri, yang semakin ketat persaingannya dan sarat proteksi, termasuk dari negara-negara maju. ESCAP (Economic Social Commission for Asia Pacific, 1988) melaporkan :

"........ By the 1980 in many developing countriers, even outside the newly industrializing countries, the value of exports of manufactures had exceeded that of primary products. However, because of both increasing protection in developed market economies and competition among developing countries in exports of 
manufactures, there is an increasing need for the expansion of commodity exports......"

Apa yang dinyatakan dalam laporan tahunan ESCAP di atas jelas-jelas dialami Indonesia. Misalnya pada awal tahun 1990 lalu komoditi tekstil Indonesia pernah ditolak setelah sampai dipelabuhan negara importer (maju) terbentur oleh adanya proteksi lewat kuota impor. Ini merupakan tantangan berat bagi proses industrialisasi Indonesia yang pada saat hendak dikembangkan dalam menembus pasar dunia, bersamaan persaingan yang makin ketat dari produk industri negara lain serta berhadapan dengan tembok-tembok proteksi. Ini agaknya berbeda dengan yang terjadi pada NICs yang pada awal kemunculannya tidak menghadapi persaingan yang begitu ketat dan relatif belum banyak menghadapi proteksi.

Namun demikian dapat dicatat, berbagai komoditi industri kita belakangan ini tetap mampu menembus persaingan dan masuk ke pasar negara lain. Diperkirakan saat ini sudah sekitar $30 \%$ dari produksi industri dalam negeri yang diekspor (Sadli, 1990). Komoditi tekstil, industri kulit, kayu, bambu dan rotan, kimia dan industri logam dasar bukan besi, merupakan komoditi industri yang menonjol dalam hal ekspornya (Nasution, 1987). Bahkan komoditi tekstil dan kayu lapis (plywood) telah menjadi komoditi yang "memimpin" ekspor nonmigas secara keseluruhan, sehingga mengurangi defisit perdangan dari ekspor nonmigas kita (ESCAP, 1988). Dengan semakin tidak menentunya harga minyak di pasar dunia, dan jumlah cadangan minyak (dan gas bumi) yang pasti kian menurun, maka sektor industri diharapkan mengambil alih peran komoditi ini dalam menyumbang devisa terbesar bagi negara. Dan inilah salah satu tantangan yang mau tidak mau harus dijawab dalam proses industrialisasi kita saat ini !!
Peluang kita untuk meningkatkan produksi, dan juga efisiensi industri ini, sehingga bisa lebih bersaing, masih tetap terbuka. Sektor industri masih bisa diharapkan terus untuk menekan biaya produksinya, dan berbagai deregulasi dan debirokratisasi yang muncul beberapa tahun terakhir ini dipastikan dapat memberi andil untuk mengurangi ongkos produksi tersebut. Di samping itu, sering terdengar bahwa kapasitas produksi industri masih banyak yang belum dimanfaatkan secara penuh (under capacity). Pemanfaatan secara penuh dari kapasitas ini, jika pasar sudah tergarap, akan merupakan faktor yang penting dalam meningkatkan efisiensi ekspor kita, yang berarti meningkatkan daya saingnya di masa yang akan datang.

Namun dalam kenyataannya, upaya peningkatan ekspor ini tidaklah sesederhana yang dikemukakañ di atas. Upaya peningkatan daya saing dan pencarian pasar ekspor, bukan sesuatu yang mudah. Ini menuntut adanya promosi di pasar luas negeri, termasuk pasar-pasar baru, misalnya di Eropa Timur, China dan sebagainya. Semakin terdiversivikasinya pasaran ekspor, maka semakin stabil pula industri kita. Karena gejolak permintaan di satu pasar bisa tidak akan terlalu mengganggu permintaan secara keseluruhan, sehingga industri di dalam negeri tak perlu terganggu dengan adanya gejolak permintaan di satu-dua mitra dagang kita. Pasar Tunggal Eropa (1992) juga menuntut penggarapan yang efektif, karena besarnya potensi pasar di sini, dan lebih dari itu pasar ME bisa jadi semakin sulit dengan telah bergabungnya 12 pasar Eropa menjadi satu pasar tunggal yang tentu pertama-tama mementingkan produk dari internal mereka sendiri. Bagian pasar dari negara lain adalah "sisa para Eropa", yang harus diperebutkan secara kompetitif. Problema sejenis juga kita hadapi dalam memasuki pasar negara Amerika Utara, yang kini tiga diantaranya telah 
bergaung dalam NAFTA (North American Free Trade Agreement). Promosi saja juga tidak cukup, kalau mutu teknis, mutu pelayanan (kemampuan untuk memenuhi. order tepat waktu, tepat kualifikasi teknis, dan kemampuan supply yang konsisten) dan sebagainya tidak dapat mengimbanginya. Aspek-aspek yang terakhir ini sering masih menjadi kendala perluasan ekspor industri kita, yang kiranya harus secara terus-menerus perlu dibenari.

\section{Industrialisasi Teknologi dan Sumberdaya Manusia.}

Dalam suatu proses industrialisasi pada masa kini, maka peran penguasaan teknologi dan kesiapan sumberdaya manusia merupakan unsur yang sangat penting. Investasi dan inovasi produksi yang dapat melahirkan produk-produk baru berkualitas, atau mengembangkan produk-produk yang sudah ada sehingga menjadi lebih efisien dan dapat diterima oleh pasar, menuntut adanya suatu penguasaan dan pengembangan teknologi yang terus menerus. Technological challanges (tantangan teknologis) ini harus dijawab oleh pelaku-pelaku di sektor industri, pemerintah maupun kalangan pendidikan tinggi. Untuk penciptaan atau pengembangan teknologi baru, maka aktivitas R\&D (research and development) mutlak untuk mendapat perhatian lebih besar." Aktivitas ini jelas memerlukan biaya yang sangat tinggi, yang untuk negara seperti Indonesia menuntut adanya kerja sama dunia bisnis dan pemerintah melakukannya secara bersamasama. (Pola kerja sama bagaimana yang bisa dilakukan untuk melakukan $\mathrm{R}$ and D ini ??)

Di samping lewat penelitian dan pengembangan yang dilakukan sendiri, maka proses alih teknologi seperti yang sudah dilakukan selama ini, tetap diperlukan. Proses alih teknologi ini selain dapat menekan biaya, juga merupakan jalan pintas yang bisa mempercepat kita menguasai téknologi baru yang sudah ditemukan atau diterapkan pihak lain dalam dunia industri. Proses alih teknologi ini sudah berjalan lewat proyekproyek PMA serta lewat technological licensing arrangements, yakni melalui lesensi dari pihak asing untuk menggunakan teknolognya atau lewat bantuan teknis langsung dari teknisi luar. Proses-proses seperti ini telah berlangsung, baik dilakukan swasta maupun BUMN. Masih ada jalur-jalur alih teknologi lainnya yang tentunya dapat dimanfaatkan oleh kita dalám mendukung industrialisasi ini.

Dalam jangka panjang, upaya yang serius dan terus menerus untuk membangkitkan hasrat masyarakat luas untuk meminati masalah-masalah yang berkaitan dengan teknologi perlu kita tumbuh-kembangkan. Minat yang luas, yang mungkin ditumbuhkan sejak usia dini, akan bisa melahirkan para investor dan inovator yang menemukan dan mengembangkan' teknik produksi yang sudah ada, yang jelas sangat dibutuhkan dalam proses industrialisasi ini. Jepang dan Korea selatan merupakan contoh sukses negara yang melakukan hal ini, bahkan juga dalam "memfoto-kopi" teknologi dari negara Barat.

Aspek terakhir yang akan dikemukakan dalam makalah ini adalah menyangkut sumberdaya manusia, khususnya yang berkerja dalam sektor industri. Dalam proses industrialisasi, maka tak dapat dipungkiri akan pentingnya dukungan sumberdaya manusia yang berkualitas, berpendidikan, cakap dan memiliki ketrampilan prima. Ini mengingat industrialisasi sering dikaitkan dengan teknologi tinggi (hi-tech) atau bahkan yang lebih tinggi lagi, yakni sophisticated technology..Walaupun bayangan ini tidak semuanya benar, mengingat dalam industrialisasi juga tetap tidak melupakan peran industri kecil dan kerajinan yang masih berteknologi "tradisional", akan tetapi dalam proses mendukung "industrial growth", maka pemikiran tentang tuntutan sumberdaya yang 
berkualitas itu tidaklah terlalu menyimpang (Hamid, Edy Suandi, 1987).

Bagaimana kondisi ketenagakerjaan kita dilihat dari kualitasnya ? Sumberdaya manusia kita sering dicap sebagai berkualitas rendah, kurang produktif dan sejenisnya. Jika dilihat dari latar belakang pendidikan angkatan kerja kita, maka pernyataan demikian tidak dapat dipungkiri. Dari 74,92 juta angkatan kerja kita pada tahun 1988, sebanyak 58,76 juta $(78,43 \%)$ hanya berpendidikan SD ke bawah, termasuk 11,96 juta yang tidak mengenyam bangku sekolah.

Dalam sektor industri, gambaran yang sama juga diperoleh. Pada tahun 1988 tersebut, dari 5,90 juta angkatan kerja yang bekerja pada sektor industri, sebanyak lebih dari $71 \%$ hanya berpendidikan SD atau kurang. Secara rinci tingkat pendidikan angkatan kerja di sektor industri ini adalah sebagai berikut (BPS, 1989) :
Tidak/belum pernah sekolah

Tidak/belum tamat SD

Sekolah Dasar

SMTP Umum

SMTP Kejuruan

SMTA Unum

SMTA Kejuruan

Diploma I / II

Akademi / Diploma III

Universitas
$596.186(10,11 \%)$

$1.319 .126(22,36 \%)$

$2.279 .127(38,64 \%)$

$659.674(11,18 \%)$

$113.793(1,93 \%)$

$502.918(8,53 \%)$

341.108 ( 5,78\%)

$10.531(0.18 \%)$

$50.728(0.43 \%)$

$27.201(0,47 \%)$
Data diatas sudah "berbicara" banyak mengenai kondisi pendidikan yang akan berpengaruh terhadap tingkat produktivitasnya para pelaku di sektor industri kita. Mereka inilah yang telah dan akan mendukung proses industrialisasi yang kini berlangsung. Gambaran ini menunjukkan bahwa pekerjaan di sektor industri, yang diharapkan mempunyai ketrampilan khusus dan tinggi, ternyata tak banyak beda dengan pekerjaan di sektor lainnya. Upaya untuk meningkatkan pendidikan formal para pekerja industri kita, jelas tidak bisa dilakukan dalam waktu singkat. Jalan pintas yang bisa dilakukan untuk meningkatkan kualitas pekerjaan industri ini adalah memberikan pelatihanpelatihan, on the job training, dan sejenisnya secara terus menerus dan berkesinambungan, merupakan strategi yang dapat dipakai untuk mencapai maksud tersebut.

Namun demikian data tingkat pendidikan tersebut perlu juga dilihat secara hati-hati. Para pekerja industri kita, sebagian besar adalah pada industri kerajianan dan industri kecil. yang menurut Sensus Ekonomi 1986 meliputi $68 \%$ dari keseluruhan tenaga kerja yang bekerja pada sektor Industri. Padahal, jika dilihat dari nilai outputnya industri kerajinan dan industri rumah tangga ini hanya menyumbang nilai output sekitar $18 \%$ dari total output sektor industri. Dengan demikian, jika dilihat dari nilai produksi ini maka pendukung utama sektor industri kita adakah industri besar dan sedang. Ini memberikan indikasi pula bahwa dari sebagian tenaga terdidik, yang jumlahnya sangat terbatas, pada sektor industri kita terserap pada industri besar dan sedang.

Akan tetapi, kenyataan tersebut di atas tidak menghapuskan "rekomendasi" akan pentingnya upaya peningkatan ketrampilan secara terus-menurs dari tenaga kerja industri kita, termasuk yang bekerja pada industri kecil dan kerajinan (IKK). Bagaimanapun kecilnya kontribusi IKK atas output sektor industri maupun PDB secara keseluruhan, akan tetapi sektor ini tidak boleh luput dari perhatian kebijaksanaan industrialisasi nasional. Kemampuannya yang besar dalam menyerap tenaga kerja industri, merupakan andilnya yang tak bisa diabaikan disaat masalah kurangnya kesempatan kerja masih (dan tetap akan) merupakan salah satu masalah paling serius dalam perekonomian kita. Di samping itu IKK ini juga banyak memanfaatkan potensi sumberdaya lokal yang ada, terutama dipedesaan, yang umumnya mengait pada pengolahan hasil pertanian. Dengan demikian, sektor IKK ini tetap terus 
dijaga kelangsungan hidupnya, dan perlu terus dikembangkan sehingga mempunyai peran lebih besar dalam perekonomian.

\section{Penutup.}

Demikianlah "sekilas wajah" dari industrialisasi di Indonesia. Dengan pemaparan wajah industri kita masa lalu dan masa kini dan problematik dan tantangan yang melekat di dalamnya, maka kita bisa pada kesimpulan yang berbeda-beda mengenai "wajah masa depan industrialisasi nasional. Skenario yang pesimistik ataupun optimistik bisa saja muncul bersamaan, tergantung pada bagaimana kita melihat kemampuan sektor industri kita memperbaiki "bopeng-bopeng" - berupa inefisiensi dan rendahnya daya saing -- yang melekat pada sektor industri kita, serta kemampuannya dalam meluaskan pasamya di arena internasional.

Berbagai kebijaksanaan pemerintah yang belakangan ini mulai mengendur proteksi, serta adanya deregulasi dan debirokratisasi, merupakan peluang besar yang bisa di manfaatkan oleh pelaku di sektor industri untuk meningkatkan efisiensinya. Jika peluang ini bisa dimanfaatkan, dan pelaku industri kita mampu menjawab tantangantantangan yang dikemukakan pada bagian sebelumnya maka berbagai sasaran pembangunan industri kita, baik sasaran kualitatif -- antara lain menciptakan kesempatan kerja yang luas hingga meningkatkan kemampuan ekspor hasil industri -- serta sasaran kuantitatif -- yang dalam Pelita diproyeksikan pertumbuhan rielnya rata-rata $8,5 \%$ per tahun -- akan bisa menjadi kenyataan.

\section{KEPUSTAKAAN}

Anwar, Mohammad Arsyad. "Industrialisasi, Tanspormasi, Struktur Produksi dan
Perdagangan Luar Negeri," dalam Hendrá Esmara (eds), Teori ekonomi dan Kebijaksanaan Pembangunan Gramedia, Jakarta, 1987.

Ariff, Mohamed dan Hall Hill. Industrialisasi di ASEN Lembaga Penelitian, Pendidikan dan Penerangan Sosial (LP3ES), Jakarta, 1988.

Bank of Indonesia. Report for the Financial Year (varlous Years). Bank Indonesia, Jakarta, various years.

Biro Pusat Statistik (BPS), Statistik Indonesia 1988, BPS, Jakarta, 1989.

, Indikalor Industri 1986, 'BPS, Jakarta, 1988.

Boediono and Pangestu, Marie. "The Structure and Causes of Manufacturing Sector Protection in Indonesia, "in Christipher Findly and Ross Garnaut (eds). The Political Economy of Manufacturing Protection Experiences of ASEAN and Australia, Allen and Unwin, Sydney, London, Boston, 1986.

Boediono. "Strategi Industrialisasi dan Pendekatan Integratif," makalah Seminar Nasional Struktur Industri, AU Studi Ekonomi UGM, Yogyakarta, 1987.

Djojohadikusumo, Sumitro. Indonesian Economic Development During Four Five Year Plans. Center for Policy StudiesIkatan Sarjana Ekonomi Indonesia, Jakarta, 1989.

Economist Intelligence Unit (EIU). Country Profile : Malaysia and Brunai 19881989. EIU, London, 1989.

Hamid, Edy Suandi. "Beberapa Aspek Ketenagakerjaan dalam Industrialisasi," dalam majalah UNISIA, Nomor 11/1987, UII Yogyakarta, 1987.

-.--.-, Indonesia in ASEAN Trade Cooperation: The Impacts of Tariff Reductions on Indonesian Imports, Thammasat University, Bangkok, 1990. -, "Ekspor Komoditi Berteknologi Tinggi: Prospek dan Tantangannya", supplementary paper dalam Seminar Nasional Prospek Ekspor Komodili Berteknologi Tinggi, UII, Yogyakarta, 1987.

, dan Hudiyanto., "Pola Bapak Angkat, 
Pembinaan dan Ekspoitasi", makalah dalam Seminar Nasional Konsep Bapak Angkat dalam Pengembangan Kemampuan Teknologi dan Manajemen Industri Kecil, Teknik Kimia, Fakultas . Teknik UGM, 1990.

Haroon, Rahman and Isa, Mansoor Md. "Nontariff Barriers to Expanding Intra-ASEAN Trade : Malaysia's Perception." ASEAN Economic Bulletin. vol. III. No. 1, July 1987, ISEAS Singapore, 1987.

Humaidi, Mochtar dan Nurimansyah Hasibuan, Analisa Statistik Industri Besar dan Sedang, BPS dan P3EM FE UNSRI, 1988.

Lembaga Penyelidikan Ekonomi dan Masyarakat Fakultas Ekonomi Universitas Indonesia (LPEM-UI). ASEAN Co-operation in Second Phase Import Substitution : Indonesian Version. LPEM-UI, Jakarta, 1986.

Nasution, Darmin. "Industrialisasi Indonesia : Pendekatan Keunggulan Komparatif," makalah Seminar Nasional Struktur Industri, PAU Studi Ekonomi UGM, 1987.

Poot, Huib, Arie Kuyvenhoven dan Jaap Jansen. Industrialisation and Trade in Indonesia. UGM Press, Yogyakarta, 1990.

Sadli dan Thee Kian Wie, "Industri, Teknologi dan Sumberdaya Alam," makalah dalam Kongres ISEI XI, Bandung, 1990

Tin, Ooi Guat, "Non Tariff Barriers to Expanding Intra Asean Trade," ASEAN Economic Bulletin, Vol. IV, No. I, Juli 1987, ISEAS, Singapore, 1987.

UN-ESCAP, Economic and Social Survey of Asia and the Pacific, UN-ESCAP, Bangkok, various years.

World Bank, The World Bank Annual Report 1989. World Bank, Washington DC, 1989.

, The World Bank Development Report 1989, World Bank, Washington DC, 1989. 